METALLURGY AND FOUNDRY ENGINEERING - Vol. 35, 2009, No. 2

Paweł Chyła***, Aneta Łukaszek-Sołek**, Jan Sińczak*

\title{
STRAIN DISTRIBUTION IN COGGING PROCESS OF INGOTS WITH INTERNAL DISCONTINUITIES
}

\section{INTRODUCTION}

The analysis of open die forging process requires discussion of the quality of forging ingots (surface, microstructure, internal defects, distribution of non-metallic inclusions and purity degree). That quality which afford with forging process parameters, deformation schedule (effective strain, degree of forging) and state of stress that metal forming effect is reached in forged part continuity, structure homogeneity and required properties.

Solidification process of steel in ingot mould, depending on casting conditions, ingot size and chemical composition, causes evolution of microstructure in particular layers and zones of ingot according to the principles of their selective creating: chilled crystals zone, columnar crystals zone, transition zone, segregation zone, equiaxed crystals zone.

Solidificated ingot is usually composed of three crystal zones: chilled crystals zone, columnar crystals zone, equiaxed crystals zone. The kinetics of solidification process and chemical composition influences the size and distribution of these zones. Ingot is characterized by different kind of inhomogeneity and defects. External defects are for example: surface cracks, flakes, spatters and the incurrence of casting powders. Internal defects are: shrink hole, shrinkage porosity and internal voids, hydrogen-induced cracks, stress-induced cracks, segregation of alloying constituents and impurities [1].

Investigations of the methods of closing the metallurgical defects (voids in cast material) in the cross-section of forgings show that closing up the metallurgical defects in deformed forgings is significantly influenced by the main forging process parameters, such as draft, relative bite, stock temperature and shape and dimensions of anvils [2, 3, 4].

This paper presents the results of studies connected with forging process, which main task except demanded shape of forged part also is to obtain suitable structure of deformed metal.

* Prof. Ph.D., D.Sc., ** Ph.D., *** M.Sc.: Faculty of Metals Engineering and Industrial Computer Science, AGH - University of Science and Technology, Kraków, Poland; e-mail: pchyla@metal.agh.edu.pl 
Checking the course of closing internal discontinuities through physical modelling is complicated and labour consuming. However, thanks to computer programs, there is a possibility of checking fundamentals of plastic working by numerical methods. The course of numerical modelling and discussion of results is the objective of this paper.

Range of conducted investigations included deforming of $16 \mathrm{Mg}$ mass forging preform into $950 \mathrm{~mm}$ diameter ingot. Ingot was cast from NiCrMoV alloy steel. Axial voids with variables diameters and also voids inclined under different angle into so prepared ingot were introduced. The forging process was carried out with use of hydraulic press and flat anvils of $1300 \mathrm{~mm}$ width and $200 \mathrm{~mm}$ corner radius.

\section{NUMERICAL CALCULATIONS}

This study presents the analysis of upsetting and cogging of $16 \mathrm{Mg}$ mass ingot to check how deformation schedule influences on introduced voids.

Numerical analysis was carried out for two consecutive forging operations:

- upsetting reforged ingot (of $2470 \mathrm{~mm}$ length and $950 \mathrm{~mm}$ diameter) to $1100 \mathrm{~mm}$ height (Fig. 1a and 1b),

- cogging to $1000 \mathrm{~mm}$ diameter (Fig. 1c and 1d).

a)

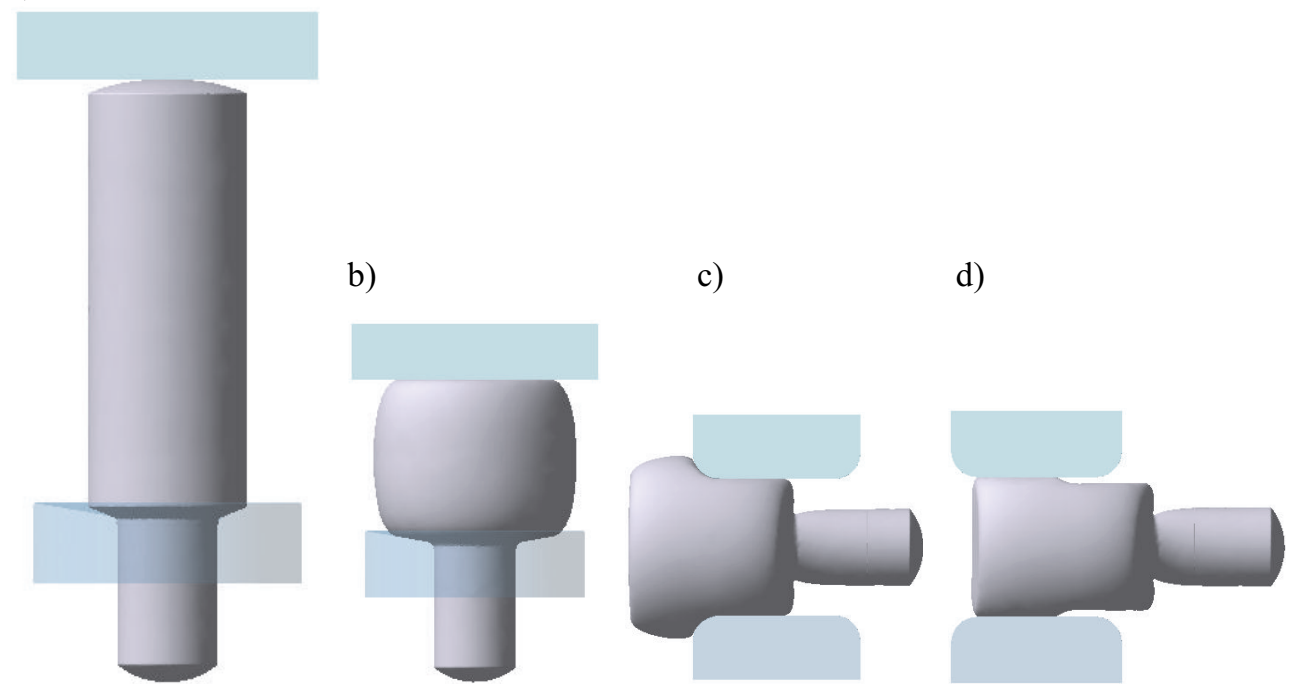

Fig. 1. The following stages of calculations on example of forging ingot from the head of the ingot: a) reforged ingot; b) preform after upsetting; c) ingot after first deformation in cogging operation; d) ingot after second deformation in cogging operation [5]

For the analysis of forging, a commercial QForm 3D program was used. This program is based on finite element method. It allows for thermo-mechanical simulation of plastic deformation in three-dimensional strain state. 
In numerical calculations was used $\mathrm{NiCrMoV}$ steel, for which were prepared flow curves for following temperatures: $800^{\circ} \mathrm{C}, 900^{\circ} \mathrm{C}, 1000^{\circ} \mathrm{C}, 1100^{\circ} \mathrm{C}, 1200^{\circ} \mathrm{C}$ and $1250^{\circ} \mathrm{C}$ as well as three strain rates: 1,10 and $40 \mathrm{~s}^{-1}$.

Into reforged ingot voids were introduced along its main axis of about 20, 40 and $50 \mathrm{~mm}$ diameter (Fig. 2b, 2c, 2d). In next variants the voids were oriented in following way: vertically (perpendicularly to main axis - Fig. 2f) as well as sloping under angle $45^{\circ}$ and $135^{\circ}$ (transverse - Fig. $2 \mathrm{e}, 2 \mathrm{~g}$ ) to the ingot main axis, all of $40 \mathrm{~mm}$ diameter.

a)

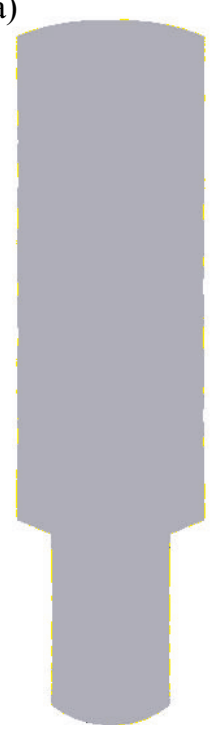

e)

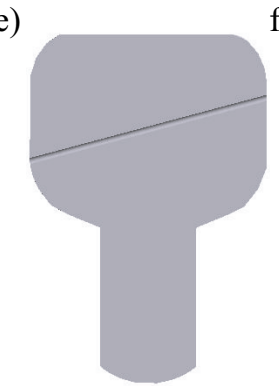

b)

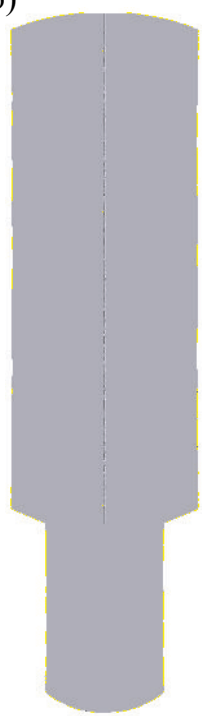

f) c)

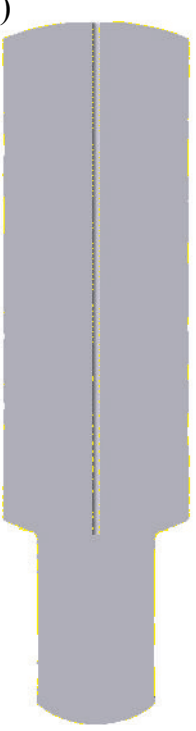

d)

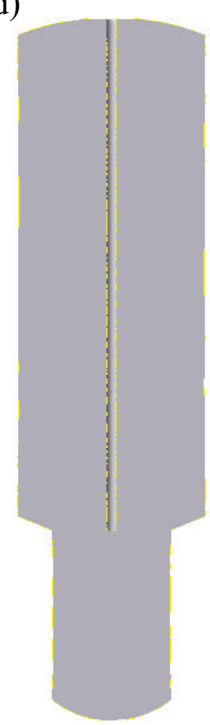

g)
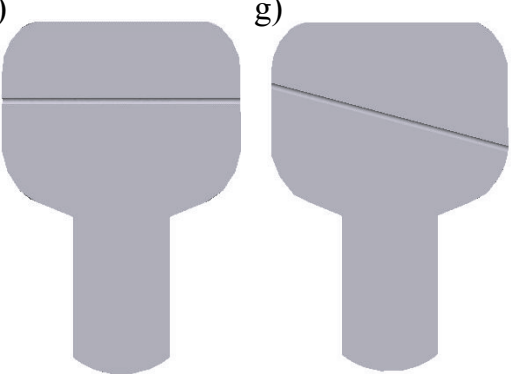

Fig. 2. Transverse sections of reforged ingots: a) without void; b) axial void $20 \mathrm{~mm}$ diameter; c) axial void $40 \mathrm{~mm}$ diameter; d) axial void $50 \mathrm{~mm}$ diameter; e) void under angle of $45^{\circ}$ to main axis; f) void under angle of $90^{\circ}$ to main axis; $g$ ) void under angle of $135^{\circ}$ to main axis [5]

Cogging operation of reforged material was simulated according to two schedules (Fig. 3):

- deformation in two next drafts with relative bite 0.5 first from porter side (the head of the ingot),

- deformation in two next drafts with relative bite 0.5 first from the bottom of the ingot. 


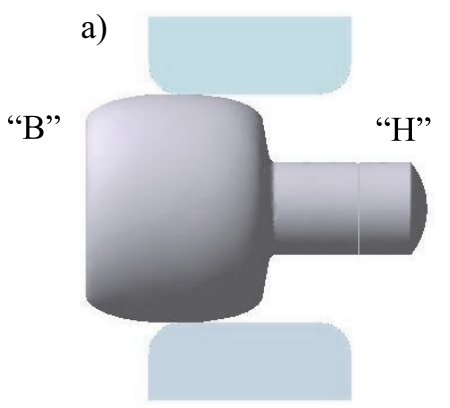

b)

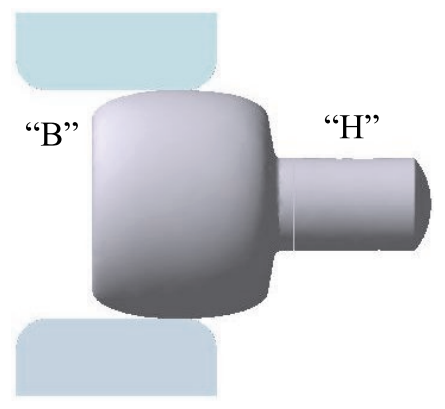

Fig. 3. Schedules (directions) of forging process: a) starting from the head of the ingot (" $H$ "); b) starting from the bottom of the ingot - " $B$ " [5]

For unification of the conditions were accepted deformation degree in upsetting operation $\varepsilon_{\mathrm{h}}=55.47 \%$, and in cogging operation $\varepsilon_{\mathrm{c} 1}=27.77 \%$ (first deformation) and $\varepsilon_{\mathrm{c} 2}=32.91 \%$ (second deformation).

Boundary conditions for calculations were following: ingot temperature before forging process $1200^{\circ} \mathrm{C}$; tools temperature $300^{\circ} \mathrm{C}$; friction factor 0.4 ; velocity of press cross-bar $10 \mathrm{~mm} / \mathrm{s}$.

\section{RESULTS OF NUMERICAL CALCULATIONS}

The following figures are introduced results of computer simulations for ingots without axial voids as well as ingots with axial voids with different diameter, and also located under $45^{\circ}, 90^{\circ}$ and $135^{\circ}$ angle to the main axis of the ingot, for which obtain effective strain distributions.

Effective strain distribution - In Figure 4 are shown maps of effective strain distribution for ingots without voids additionally are presented maximal and minimal values of effective strain.

For all presented forging cases effective strain distribution is similar in zone II and III, testifying that uneven metal flow during symmetrical upsetting, as also in two cogging operations. These differences in effective strain distribution have direct influence on structure and mechanical properties of preform. Maximal values of effective strain are concentrated in axial zone of reforged ingot and equal properly: 1.067, 1.837 and 2.469 .

The influence of effective strain on voids closing is shown in Figures 5-11.

As it is shown in Figures 5-11 plastic deformation of ingots with introduced voids according to individual variants clearly differentiates effective strain topography in characteristic zones of plastic deformation. In upsetting operation voids situated in central part of the ingot increase almost twice from initial diameter in whole range of preset relative deformation. Analysis of these data it is possible to affirm, that upsetting operation influence on void closing is clearly unfavourably and leads to enlarging of initial voids size. During second deformation in cogging operation is displayed gradual closing of void with initial $20 \mathrm{~mm}$ diameter from the head of the ingot, until to total closing from the bottom of the ingot. 
a)

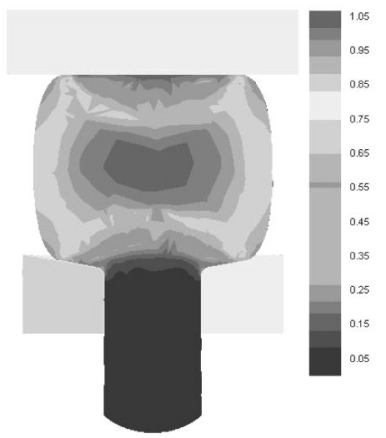

$\max : 1.067$ min: 0

b)

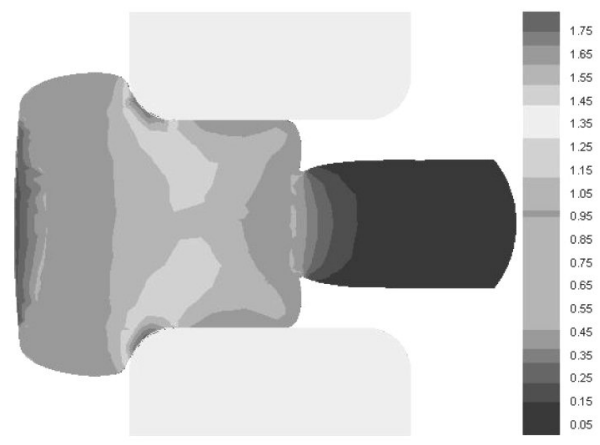

$\max : 1.837$ min: 0.006756

d)

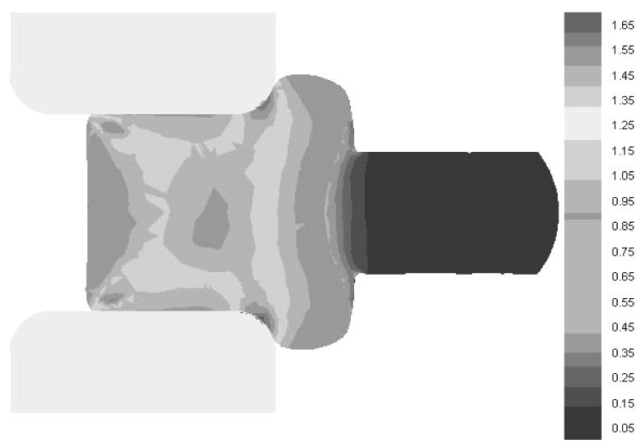

$\max : 1.701$ min: 0.006756 c)

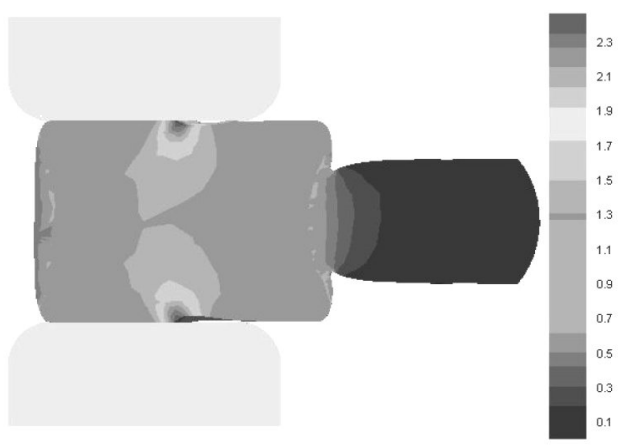

$\max : 2.469 \min : 0.008681$

e)

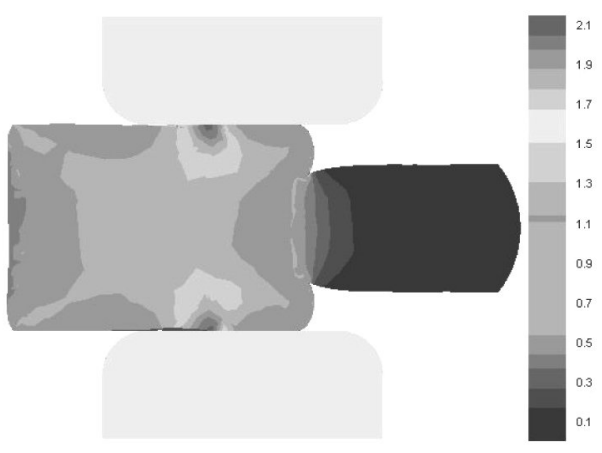

$\max : 2.150 \min : 0.009149$

Fig. 4. Effective strain distribution for ingots without voids: a) after upsetting operation; b) and c) after first and second deformation in cogging operation in case of forging from the head side; d) and e) after first and second deformation in cogging operation in case of forging from the bottom side [5] 
a)

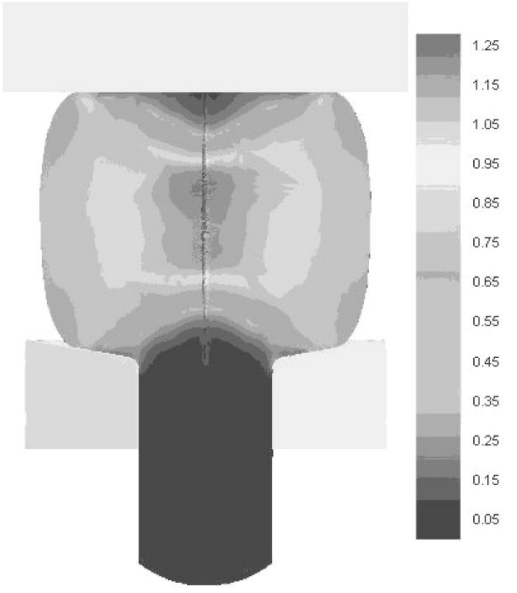

b)

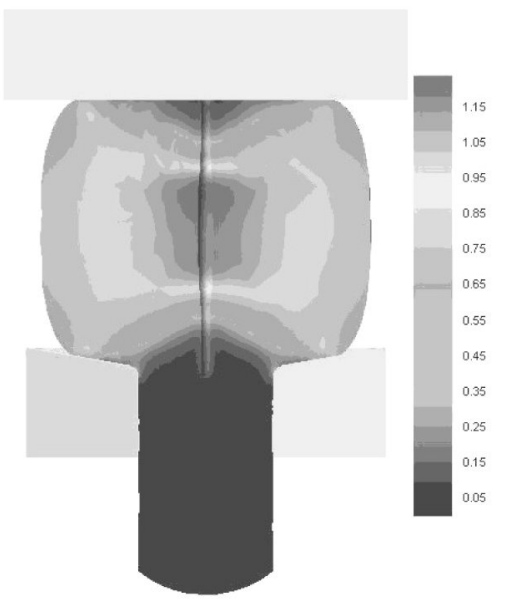

c)

Fig. 5. Effective strain distribution after upsetting operation for ingots with voids: a) $20 \mathrm{~mm}$; b) $40 \mathrm{~mm}$; c) $50 \mathrm{~mm}$ diameter [5]

Axial voids with $40 \mathrm{~mm}$ diameter in second deformation in cogging operation gets smaller clearly in both forging cases from the head and the bottom of the ingot, but it does not entirely close on whole length. From left side of the preform from surface of the head front is visible the trace of defect and similarly from the bottom of the ingot ( 2 traces), which testifies that defect of this size became non-welded beside these parameters of process. Only central part of preform fulfils qualitative requirements. Visible confirmation of non-welded void effect is case of forging ingot with $50 \mathrm{~mm}$ diameter defect, stepping out in front zone and near porter /so called zone III - that is plane unrestricted with surface of anvil in open die forging - ingot borders/. Not without meaning is phenomena of open metallurgical defect oxygenation. 
a)

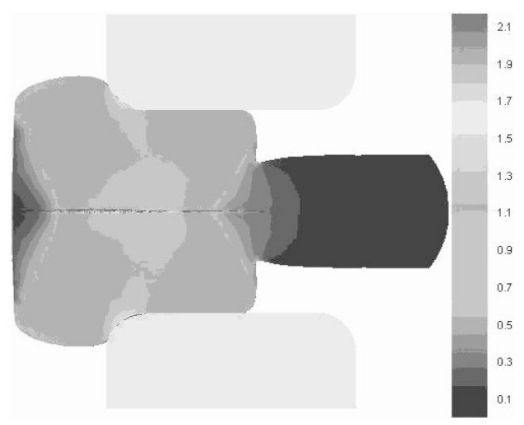

b)

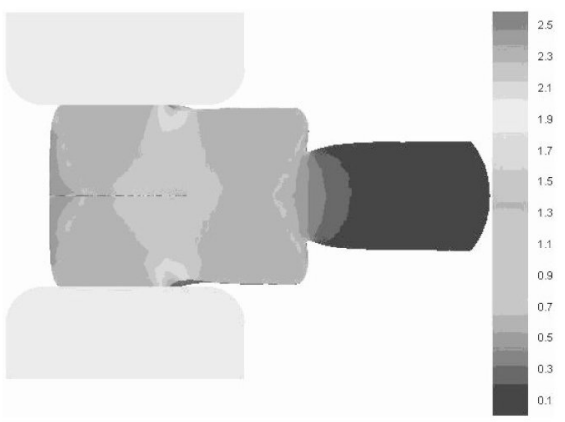

c)

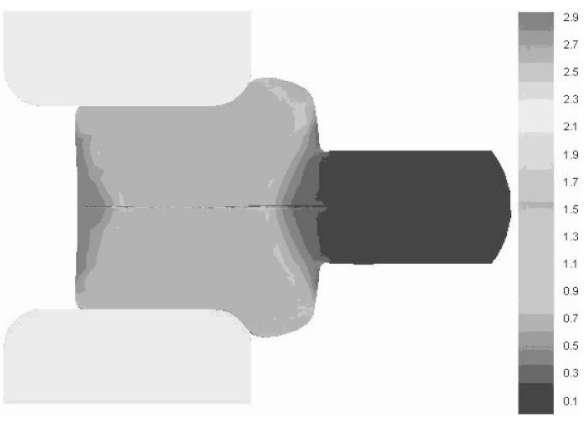

d)

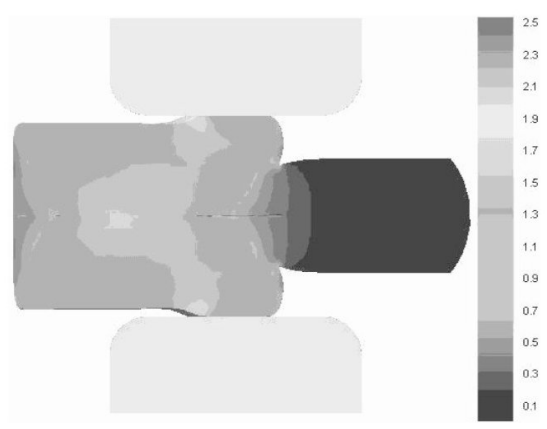

Fig. 6. Effective strain distribution for ingots with $20 \mathrm{~mm}$ diameter void: a) and b) after first and second deformation in cogging operation in case of forging from the head side; c) and d) after first and second deformation in cogging operation in case of forging from the bottom side [5] 
a)

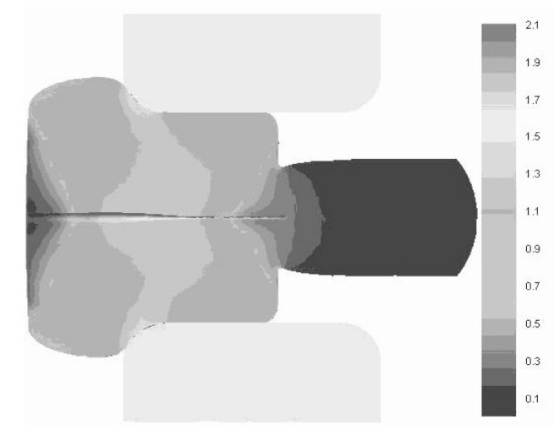

b)

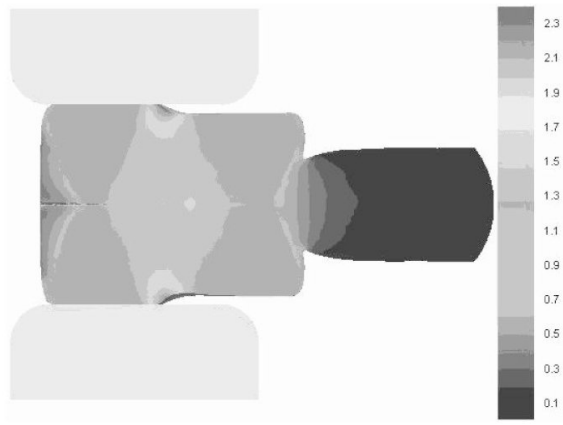

c)

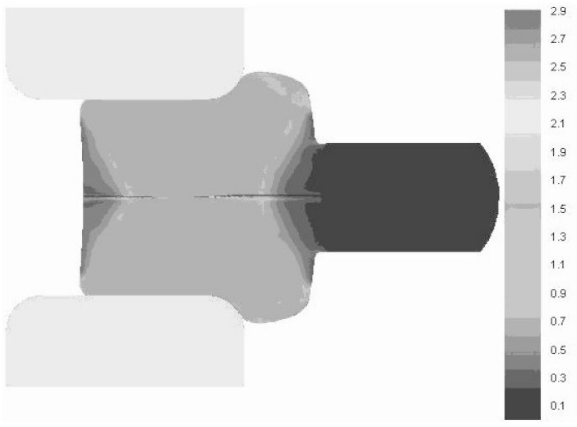

d)

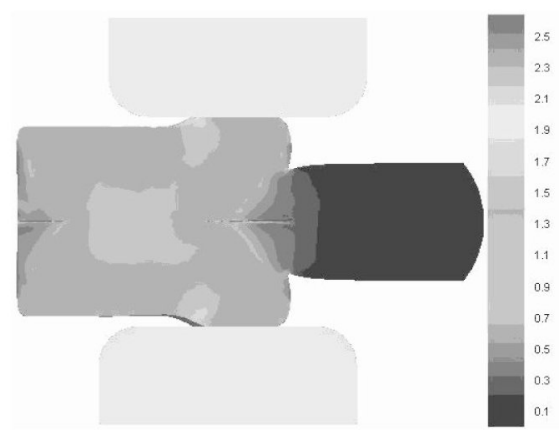

Fig. 7. Effective strain distribution for ingots with $40 \mathrm{~mm}$ diameter void: a) and b) after first and second deformation in cogging operation in case of forging from the head side; c) and d) after first and second deformation in cogging operation in case of forging from the bottom side [5] 
a)

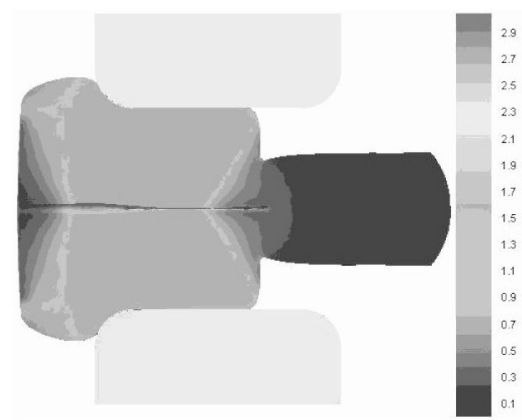

b)

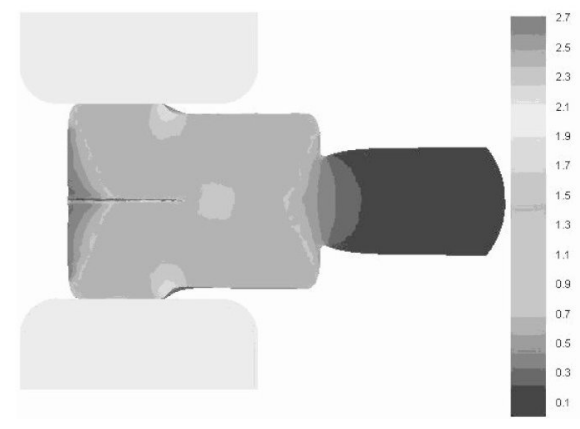

c)

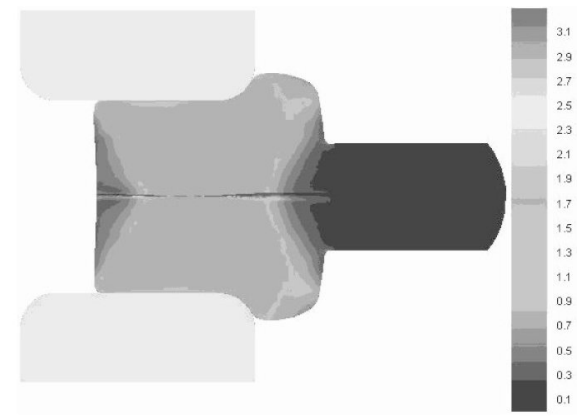

d)

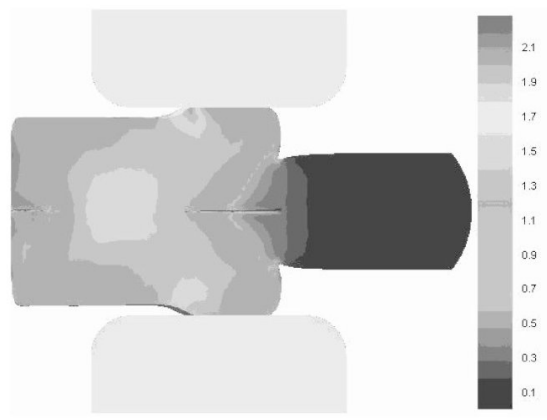

Fig. 8. Effective strain distribution for ingots with $50 \mathrm{~mm}$ diameter void: a) and b) after first and second deformation in cogging operation in case of forging from the head side; c) and d) after first and second deformation in cogging operation in case of forging from the bottom side [5] 
a)

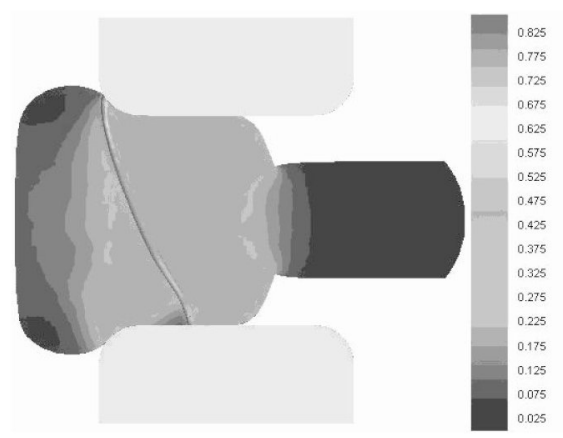

b)

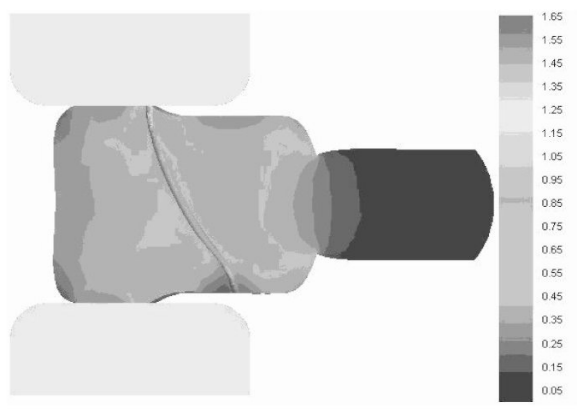

c)

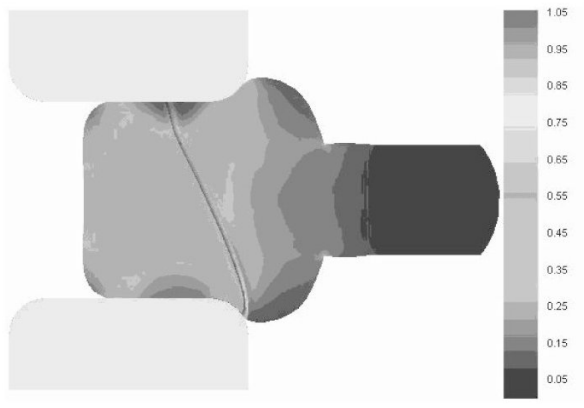

d)

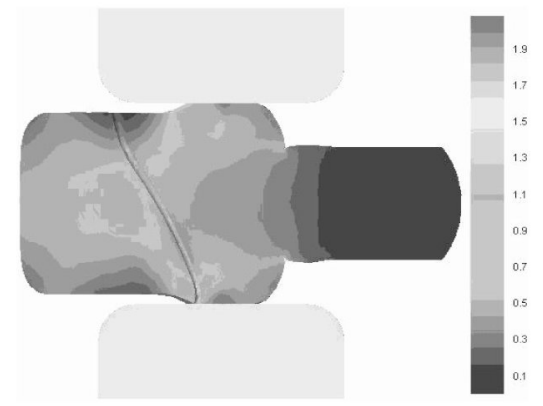

Fig. 9. Effective strain distribution for ingots with $40 \mathrm{~mm}$ diameter void under $45^{\circ}$ angle to the main axis of ingot: a) and b) after first and second deformation in cogging operation in case of forging from the head side; c) and d) after first and second deformation in cogging operation in case of forging from the bottom side [5] 
a)

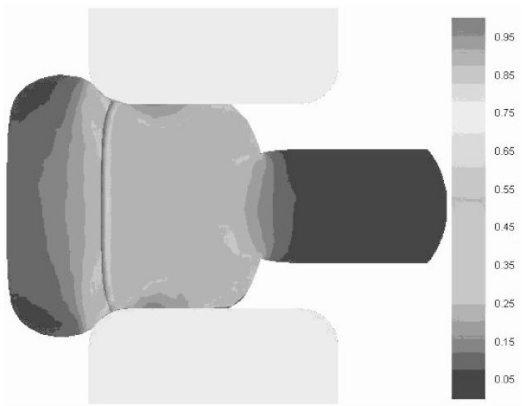

b)

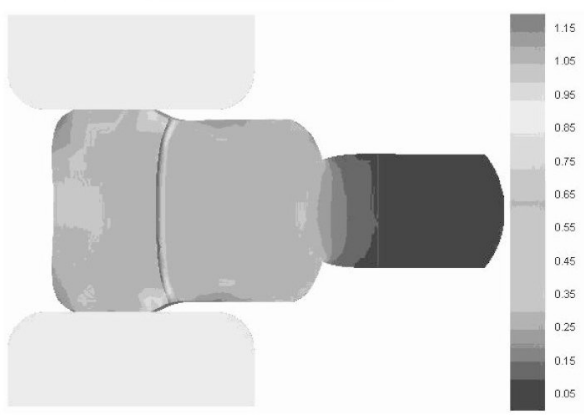

c)

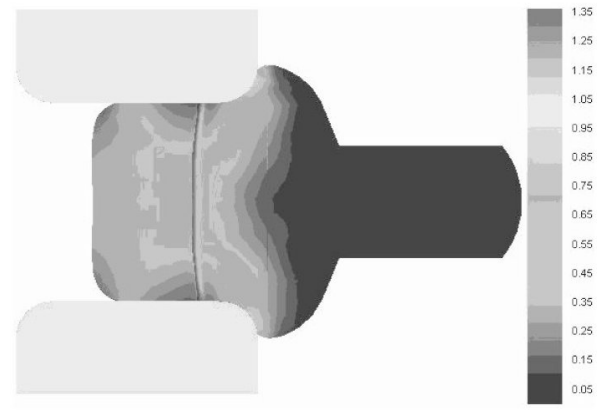

d)

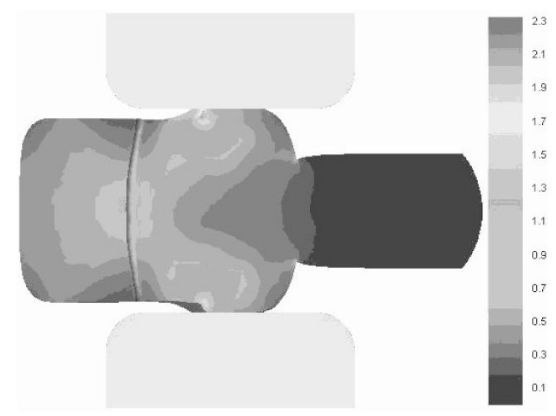

Fig. 10. Effective strain distribution for ingots with $40 \mathrm{~mm}$ diameter void under $90^{\circ}$ angle to the main axis of ingot: a) and b) after first and second deformation in cogging operation in case of forging from the head side; c) and d) after first and second deformation in cogging operation in case of forging from the bottom side [5] 
a)

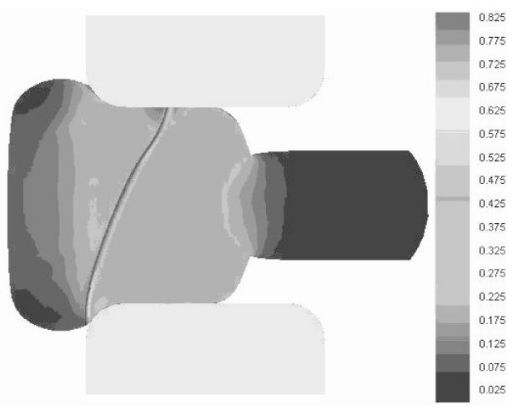

b)

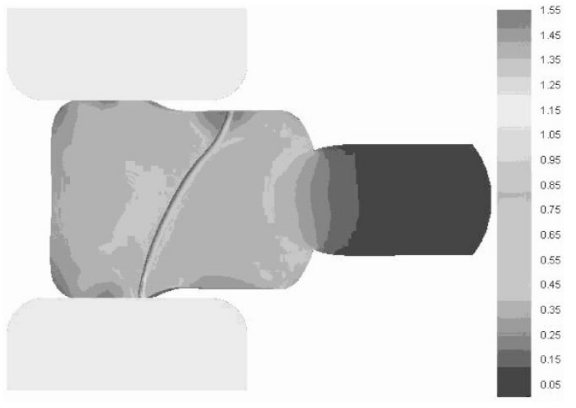

c)

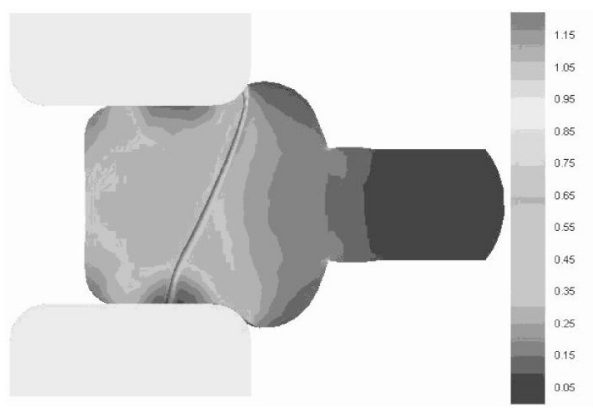

d)

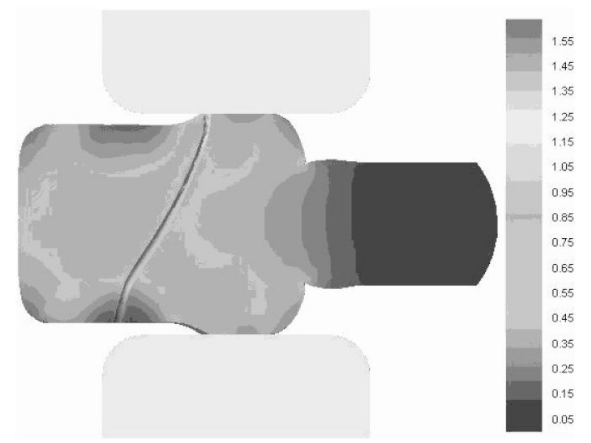

Fig. 11. Effective strain distribution for ingots with $40 \mathrm{~mm}$ diameter void under $135^{\circ}$ angle to the main axis of ingot: a) and b) after first and second deformation in cogging operation in case of forging from the head side; c) and d) after first and second deformation in cogging operation in case of forging from the bottom side [5] 


\section{CONCLUSIONS}

Basic source of information about metallurgical defects introduced into structure of studied ingots simulated in upsetting and cogging operation is value and effective strain distribution beside established process parameters. The effective strain in determined conditions of forging process is a parameter that most powerfully influence on size and differentiation in voids closure, and the same on final preform quality. Direction and intensity of these changes were estimated on individual tests of the ingot in one kind/species of the steel and established process parameters.

On introduced maps the value and distribution of strain is changing in dependence on the forging schedule.

The highest values of effective strain occurs in the case of ingot without voids, however in residual cases of ingots with voids this tendency is opposite.

Comparing effective strain distribution in upsetting operation of ingot without voids with the ingots with axial voids it is visible that the zone of the highest deformations is lesser in cases of forging ingots with voids. This zone is located in direct neighbourhood of defect.

\section{Acknowledgment}

The financial support from the Polish Ministry of Science and Higher Education, contract AGH no. 11.11.110.859 is gratefully acknowledged.

\section{REFERENCES}

[1] Krzekotowski Z: Technologia kucia swobodnego i półswobodnego, Wyd. Śląsk, Katowice, 1964

[2] Banaszek G., Stefanik A., Dyja H., Berski S., Janik M.: Modelowanie komputerowe i laboratoryjne procesu zamykania wad pochodzenia metalurgicznego we wlewkach podczas kucia swobodnego na gorąco, Rudy i Metale Nieżelazne, 48 (2003) 10-11, 512-517

[3] Banaszek G., Stefanik A.: Wpływ asymetrii obciążenia zewnętrznego na zamykanie wad metalurgicznych podczas kucia swobodnego na gorąco, Hutnik - Wiadomości Hutnicze, 71 (2004) 9, 468-475

[4] Banaszek G., Mróz S.: Modelowanie numeryczne procesu zamykania wad metalurgicznych podczas kucia swobodnego na gorąco w kowadłach wypukłych, Hutnik - Wiadomości Hutnicze, 72 (2005) 7-8, 383-388

[5] Chyła P.: Rozkład odkształceń w procesie wydłużania swobodnego, AGH, Kraków, 2008 (praca magisters$\mathrm{ka}$, nie publikowana)

Received

December 2009 